\title{
The Technical and Economic Study of Solar-Wind Hybrid Energy System in Coastal Area of Chittagong, Bangladesh
}

\author{
Shuvankar Podder, Raihan Sayeed Khan, and Shah Md Ashraful Alam Mohon \\ Department of Electrical and Electronic Engineering, Bangladesh University of Engineering and Technology (BUET), \\ Dhaka 1000, Bangladesh
}

Correspondence should be addressed to Shuvankar Podder; podder.shuvankar@gmail.com

Received 13 April 2015; Revised 9 June 2015; Accepted 14 June 2015

Academic Editor: Jing Shi

Copyright ( 2015 Shuvankar Podder et al. This is an open access article distributed under the Creative Commons Attribution License, which permits unrestricted use, distribution, and reproduction in any medium, provided the original work is properly cited.

\begin{abstract}
The size optimization and economic evaluation of the solar-wind hybrid renewable energy system (RES) to meet the electricity demand of $276 \mathrm{kWh} /$ day with $40 \mathrm{~kW}$ peak load have been determined in this study. The load data has been collected from the motels situated in the coastal areas of Patenga, Chittagong. RES in standalone as well as grid connected mode have been considered. The optimal system configurations have been determined based on systems net present cost (NPC) and cost of per unit energy (COE). A standalone solar-wind-battery hybrid system is feasible and economically comparable to the present cost of diesel based power plant if $8 \%$ annual capacity shortage is allowed. Grid tied solar-wind hybrid system, where more than $70 \%$ electricity contribution is from RES, is economically comparable to present grid electricity price. Moreover, grid tied RES results in more than $60 \%$ reduction in greenhouse gases emission compared to the conventional grid. Sensitivity analysis has been performed in this study to determine the effect of capital cost variation or renewable resources variation on the system economy. Simulation result of sensitivity analysis has showed that $20 \%$ reduction of installation cost results in nearly $9 \%-12 \%$ reductions in cost of per unit energy.
\end{abstract}

\section{Introduction}

The Government of Bangladesh has issued its Vision and Policy Statement in February 2008, to bring the entire country under electricity service by the year 2020 [1]. Presently, more than $40 \%$ of the total population do not have access to electricity [2]. The installed electricity generation capacity of the country is about 10,445 MW in 2014 [3]. At present, electricity demand growth in Bangladesh is about 10\% annually which is expected to increase in the coming years. Due to gas shortage and inadequate addition of new generation plants in the past few years, demand of electricity has outpaced generation capacity resulting in persistent load-shedding [4].

Present electricity generation scenario in Bangladesh is shown in Figure 1. As the figure shows, $65 \%$ of total generated electricity comes from gas.

Each year millions of tons of greenhouse gases (GHGs) are being emitted from fossil fuel based power plants. Although the per capita $\mathrm{CO}_{2}$ emission of Bangladesh is very low compared to developed countries [5], a report showed that the $\mathrm{CO}_{2}$ emission has increased from 0.1374 tons/capita in 1990 to 0.2667 tons/capita in 2007 [6]. Annual energy shortage and greenhouse gas emission, the two pressing problems, can be solved by installing renewable energy system (RES) such as solar, wind, biogas, and hydro.

The present share of renewable energy in Bangladesh is only $1 \%$ [7]. This is due to the high initial cost compared to fossil fuel based system. But renewable energy based options become economically viable when environmental cost, health hazard, and lower operating cost are taken into consideration [1].

The Government of Bangladesh has also declared its target of meeting five and ten percent of the total power demand using renewable energy by 2015 and 2020, respectively [1]. With this target at hand, government and some nongovernment organizations are conducting surveys. A joint survey by Local Government Engineering Department (LGED) and Chittagong University of Engineering and Technology (CUET) during early 2000 revealed that the average wind speed in the coastal areas of the country remains 


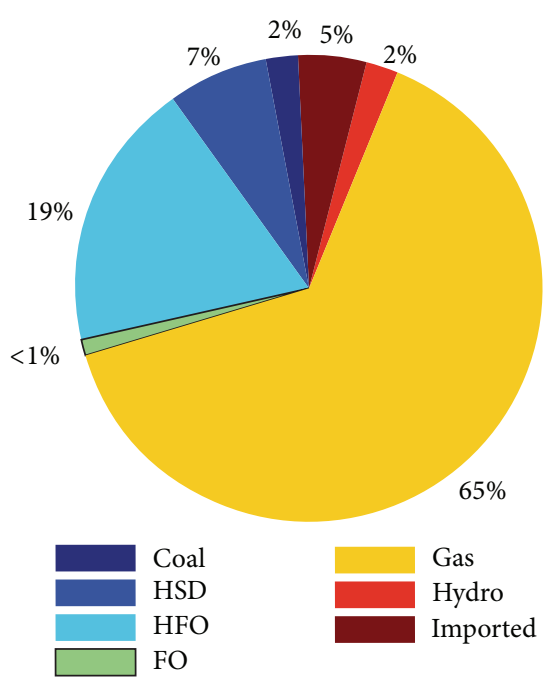

FIGURe 1: Present electricity generation scenario in Bangladesh.

between 3 and $4.5 \mathrm{~m} / \mathrm{s}$ in the months of March to September and $1.7-2.3 \mathrm{~m} / \mathrm{s}$ for remaining period of the year [8]. This survey showed that the coastal areas and islands possess good potential for generating electricity from wind energy during March to September. The average sunshine data of these areas show that the period of bright (i.e., more than $200 \mathrm{~W} / \mathrm{m}^{2}$ intensity) sunshine hours in the coastal region of Bangladesh varies from 3 to 11 hours daily and the global radiation varies from $3.8 \mathrm{kWh} / \mathrm{m}^{2} /$ day to $6.4 \mathrm{kWh} / \mathrm{m}^{2} /$ day [9]. This amount of radiation is sufficient to produce electricity using solar cells. Average wind speed at $25 \mathrm{~m}$ height studied by LGED under Solar and Wind Energy Resource Assessment (SWERA) project [8] and average solar radiation measured by NASA Surface Meteorology and Solar Energy (SSE) [10] for six coastal stations are shown in Table 1.

Generating power from RES costs more than conventional fossil fuel based plants but the cost can be minimized by combining two or more renewable energy sources. A number of studies [11-14] showed that renewable energy based standalone hybrid systems are compatible with grid electricity for remote areas where grid extension is not feasible. The optimum size of RES to supply desired load is determined in studies $[15,16]$. Alam Hossain Mondal and Sadrul Islam studied [17] the potential and viability of grid connected solar PV system in Bangladesh and found that cost of generating electricity from grid connected PV is comparable to grid connected fossil fuel based system. The optimization of hybrid energy systems for minimizing excess electricity and cost of energy is studied by Razak et al. [18]

A solar-wind hybrid power system uses solar insolation and wind energy to produce electricity. As both solar radiation and wind speed vary throughout the year, neither solar nor wind based system can provide reliable electricity individually. Wind speed remains fairly high during June to August when solar insolation is low due to cloud cover. On the other hand, wind speed remains quite low during December to February when solar radiation on earth surface
TABLE 1: Average wind speed and average solar radiation at six coastal stations.

\begin{tabular}{lcc}
\hline Location & $\begin{array}{c}\text { Average wind speed } \\
(\mathrm{m} / \mathrm{s})\end{array}$ & $\begin{array}{c}\text { Average solar radiation } \\
\left(\mathrm{kWh} / \mathrm{m}^{2} / \text { day }\right)\end{array}$ \\
\hline Kuakata & 4.52 & 4.55 \\
Patenga & 3.8 & 4.35 \\
Charfassion & 4.07 & 4.52 \\
(Bhola) & 3.34 & 4.69 \\
Cox's Bazar & 2.94 & 4.56 \\
Teknaf & 2.96 & 4.56 \\
Noakhali & & \\
\hline
\end{tabular}

is fairly high to generate electricity. Thus hybridizing solarwind system can be an alternative and reliable source of energy round the year. This hybrid system backed by storage elements/medium can supply electricity consistently and reliably. Wind-PV charge controllers regulate the charging of the energy before it is stored in the battery banks. An inverter converts the DC output of storage into AC of desired voltage and frequency.

In this study mainly two issues are examined regarding solar-wind grid connected as well as standalone hybrid power system.

(1) Is solar-wind hybrid power system feasible with available renewable energy resources at the target location?

(2) Which configuration (grid only, grid and RES hybrid, and RES only) provides the most economically viable solution, using net present cost (NPC) as the basis of comparison?

\section{Tools}

Hybrid Optimization of Multiple Energy Resources (HOMER) software [19] is chosen as the primary simulation tool for this study. This software is designed to simulate long-term operation of a combination of micropower system configurations that could include components like solar $\mathrm{PV}$, wind, hydro, diesel generators and storage devices like battery banks. It can also model grid connected systems. The reason behind choosing this software is that it can perform the three major tasks. They are simulation, optimization, and sensitivity analysis. After simulating a number of combinations based on the data supplied by the user, HOMER suggests the optimal configuration based on the lowest net present cost (NPC). Sensitivity analysis enables the designer to determine the best combination of system components under different conditions.

\section{Location of the Project}

This study is done at Patenga $\left(22.26^{\circ} \mathrm{N}, 91.8^{\circ} \mathrm{E}\right)$ which is a coastal area under Chittagong District. After assessing the potential of electricity generation from wind and solar resources in Chittagong coastal region, BPDB has planned to implement 50-200 MW wind power project at Parky beach area, Anwara, which is $32.2 \mathrm{~km}$ away from Patenga [6]. This 
study is done considering community like office and hospitals where continuous electricity supply is essential and grid electricity is not reliable. Also, standalone RES can provide electricity to remote areas like motels along coastal areas where grid electricity is not available.

\section{Renewable Resources}

4.1. Solar Resources. Solar radiation data are essential elements in PV output calculation. The accuracy of the radiation data helps to provide accurate results. The target place is Patenga, Chittagong. But direct solar radiation data for Patenga is not available from Bangladesh Meteorological Department (BMD) or any other institution. A number of studies estimated solar radiation from bright sunshine hours [23-26], while other studies estimated solar irradiance from the measurement of cloud cover in the sky $[27,28]$. As the data of bright sunshine hours of Patenga is available at BMD, in this study, solar radiation is calculated from hours of bright sunshine during a day.

The popularly known Angstrom-Prescott regression equation [29] relating ratio of monthly average daily solar radiation to average daily extraterrestrial radiation and ratio of bright sunshine hours to total day length in hours is given by

$$
\frac{\bar{H}}{\overline{\bar{H}}_{0}}=a+b \frac{\bar{n}}{\bar{N}}
$$

where $\bar{H}$ is monthly average daily global radiation (Wh/ $\mathrm{m}^{2}$ /day), $\bar{H}_{0}$ is monthly average daily extraterrestrial radiation ( $\mathrm{Wh} / \mathrm{m}^{2} /$ day), $n$ is actual sunshine duration in a day (hours), $N$ is monthly average maximum possible bright sunshine duration in a day (hours), and $a, b$ are empirical coefficients.

The values of monthly average daily global radiation $\bar{H}$ are obtained from daily measurement covering period 19832005 by NASA Surface Meteorology. The monthly average of daily hours of bright sunshine $n$ is obtained from Bangladesh Meteorological Department (BMD) and monthly average of the maximum possible daily hours of sunshine or day length $N$ is obtained from a weather based website [30].

The method of least squares was used to obtain the constants $a$ and $b$. The estimated global solar radiation according to (1) and monthly solar radiation measured by NASA over Chittagong are shown in Figure 2. From the figure it is evident that measured radiation reported by NASA from the analysis of satellite captured image and estimated radiation are close enough. In this study estimated solar radiation is used in optimizing solar panel size.

4.2. Wind Resources. Just like solar radiation data, wind speed data are also essential for hybrid system analysis. Wind speed data are obtained from BMD [31]. HOMER requires four parameters to generate hourly wind speed from provided monthly wind speed data [32]. They are listed below.

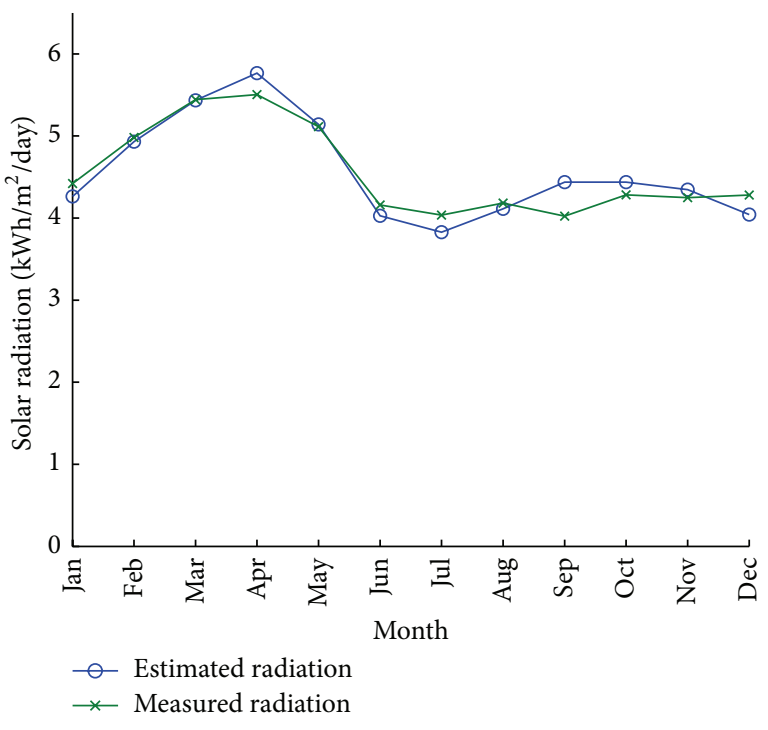

Figure 2: Estimated and measured solar radiation at Patenga.

(i) Weibull Value. The Weibull value $k$ is a measure of distribution of wind speed over the year. In this study, the value of $k$ has taken 2 .

(ii) Autocorrelation Factor. The autocorrelation factor measures the randomness of the wind. Higher value indicates that the wind speed during an hour tends to depend strongly on the wind speed during the previous hour. Lower value means that the wind speed tends to fluctuate in a more random fashion from hour to hour. The autocorrelation factor value has taken 0.78 .

(iii) Diurnal Pattern Strength. The diurnal pattern strength indicates how strongly wind speed tends to depend on the time of a day. To measure this, average wind speed at each of the 24 hours over the year is calculated. HOMER then fits a cosine function to this diurnal profile. The diurnal pattern strength is equal to the ratio of the amplitude of the cosine wave to the average wind speed. The range of diurnal pattern strength is normally 0 to 0.4 . In this study, considering wind speed moderately depends on the time of a day, the value of this parameter is chosen as 0.3 .

(iv) Hour of Peak Wind Speed. The time of day tends to be windiest on average throughout the year. In this study, $3 \mathrm{pm}$ is used as the hour of peak wind speed. Figure 3 shows the monthly average wind speed, measured at the height of $10 \mathrm{~m}$ above ground level.

\section{Electrical Load}

Seasonal load profile of proposed area is shown in Figure 4. Energy consumed by the hypothetical community is $276 \mathrm{kWh} /$ day with a peak demand of $40 \mathrm{~kW}$. Load profile is prepared by conducting survey on electricity consumption of tourist motels at Patenga. It is considered that day to 


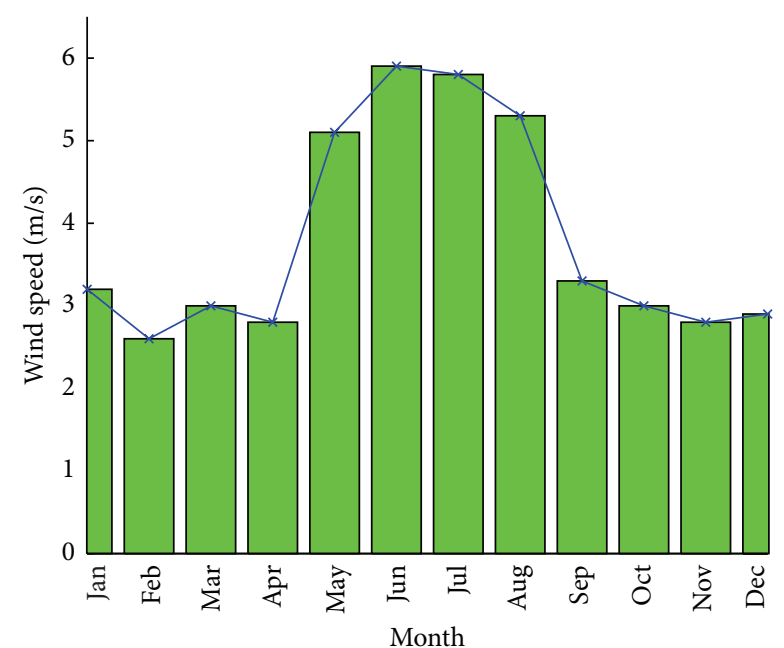

FIgURE 3: Monthly average wind speed.

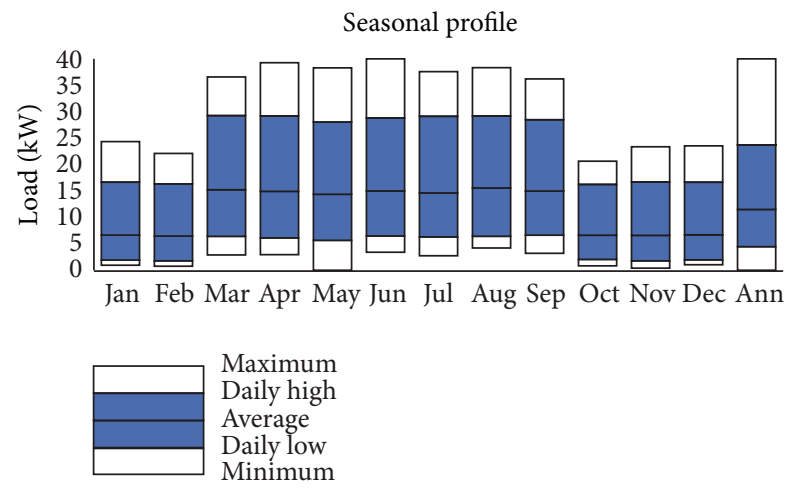

Figure 4: Seasonal load profile of proposed area.

day random variability is $15.2 \%$ and time step to time step variability is $20.4 \%$. Demand is high during summer (March-September) and low during winter (October-February). Distribution system would be required for electric service regardless of whether the service is provided by grid or standalone RES. At present, utility is providing $11 \mathrm{kv}$ line for new connection. So a $11 \mathrm{kv} / 220 \mathrm{v}$ step-down transformer is required for grid connected system. Also an Automatic Transfer Switch (ATS) is required so that, in case of inadequate supply from RES, load is being connected automatically to standby grid electricity.

\section{Hybrid System Component}

6.1. Grid. In this study, grid connected renewable energy system is compared with grid only and RES only system. In the grid connected RES, grid is used as standby supply. When energy supply is inadequate from RES due to bad weather, electricity from grid is consumed. Distribution companies impose different charges for consuming electricity from grid during peak-hours, off-peak hours, and flat rate hours. For commercial and office buildings, charges determined by
TABLE 2: Electricity consumption charge for different sectors by BPDB.

\begin{tabular}{lccc}
\hline Consumer & Time (local time) & Rate type & $\begin{array}{c}\text { Rate } \\
(\mathrm{BDT} / \mathrm{kWh})\end{array}$ \\
\hline Nonresidential & $11.00 \mathrm{am}-5.00 \mathrm{pm}$ & Flat & 9 \\
Commercial & $5.00 \mathrm{pm}-12.00 \mathrm{am}$ & Peak & 11.85 \\
Office & $12.00 \mathrm{am}-11.00 \mathrm{am}$ & Off-peak & 7.22 \\
\hline
\end{tabular}

TABLE 3: Technical parameters of PV array.

\begin{tabular}{lc}
\hline Output current & DC \\
\hline Lifetime & 20 years \\
\hline Azimuth angle & 0 degrees \\
\hline Ground reflection & $20 \%$ \\
\hline Slope & 22.05 degrees \\
\hline Derating factor & $85.50 \%$ \\
\hline
\end{tabular}

BPDB during different demand hours are shown in Table 2 [33].

6.2. Photovoltaic Array. The optimal PV array size in $\mathrm{kW}$ for concerned load is determined in this study. PV array size is dependent on technical and economical parameters of PV panel. It is assumed that PV panel output is linearly proportional to incident radiation. Technical parameters of PV array are shown in Table 3. Economical parameters are shown in Table 6. Charge controller is required to control charging and discharging of battery by PV array current and as HOMER does not provide this option the price of charge controller is merged with PV panel price.

6.3. Wind Turbine. This study uses $10 \mathrm{~kW}$ wind turbine manufactured by Yangzhou Shenzhou Wind-Driven Generator Co., Ltd., China [34]. Technical parameters of the wind turbine are shown in Table 4. Economical parameters are shown in Table 6. Power curve of this turbine is shown in Figure 5. Lifetime of considered wind turbine has taken 9 years while the lifetime of wind turbines made by Bergey Excel, Vestas, spans from 15 to 20 years. Though replacement cost for this low lifetime turbine is high, it is found from HOMER simulation that, due to low capital cost, considered turbine provides low net present cost (NPC) compared to high quality wind turbines over project lifetime. Surface area requirements for wind turbines are assessed for this study using the National Renewable Energy Laboratory (NREL) wind turbine area measurement [35]. According to NREL, average land capacity density (capacity per unit area) is $3.0 \pm$ $1.7 \mathrm{MW} / \mathrm{km}^{2}$. Therefore area required for $1 \mathrm{~kW}$ wind turbine is roughly $0.00025 \mathrm{~km}^{2}$ or $250 \mathrm{~m}^{2}$.

6.4. Battery and Inverter. As renewable resources like solar radiation and wind speed are seasonal, energy storage medium is required to get continuous supply of energy from RES. In case of grid connected RES electricity can be supplied reliably by using backup of 
TABLE 4: Technical parameters of the wind turbine.

\begin{tabular}{lc}
\hline Rated power & $10 \mathrm{~kW}$ \\
\hline Hub height & 25 \\
\hline Lifetime & 9 years \\
\hline Rotor diameter & $8 \mathrm{~m}$ \\
\hline Number of blades & 3 \\
\hline Efficiency & $0.85 \%$ \\
\hline
\end{tabular}

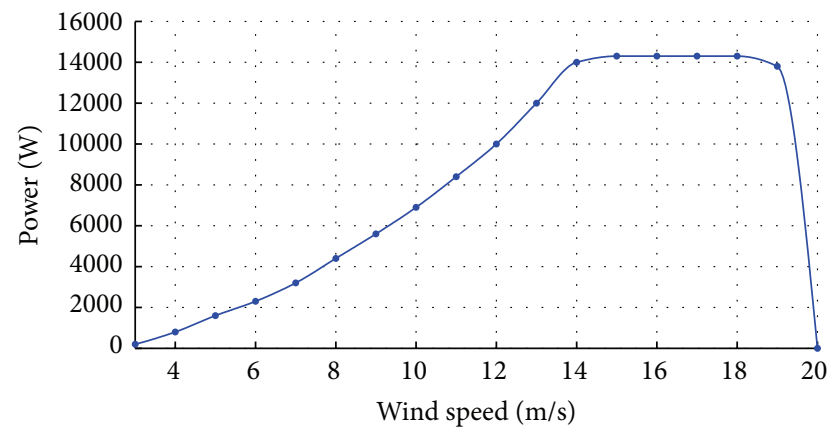

Figure 5: Power curve of the wind turbine.

TABLE 5: Technical parameters of electrosolar lead acid battery.

\begin{tabular}{lc}
\hline Nominal capacity & $130 \mathrm{Ah}$ \\
Nominal voltage & $12 \mathrm{~V}$ \\
Round trip efficiency & $80 \%$ \\
Minimum state of charge & $40 \%$ \\
Float life & $6 \mathrm{yrs}$ \\
Maximum charge rate & $0.4 \mathrm{~A} / \mathrm{Ah}$ \\
Maximum charge current & $52 \mathrm{~A}$ \\
Lifetime throughput & $2230 \mathrm{kWh}$ \\
Suggested value & $2230 \mathrm{kWh}$ \\
\hline
\end{tabular}

(1) grid supply,

(2) deep cycle lead acid batteries.

Electrosolar deep cycle, lead acid battery manufactured by Electro Solar Power Ltd., Bangladesh [36], is used in this study. Two batteries are connected in series to give $24 \mathrm{~V} \mathrm{DC}$ bus. Technical parameters of this battery are given in Table 5 . Economic parameters of this battery are shown in Table 6 .

Converter sizing is roughly in proportion to the size of the load it serves. Sizing for the case-study converters therefore ranged from 20 to $45 \mathrm{~kW}$. Economic parameters of converter are shown in Table 6.

\section{System Economics, Constraints}

The project lifetime is considered to be 25 years and the annual real interest rate $7.25 \%$ according to Bangladesh Bank [37]. The annual capacity shortage penalty and system fixed operation and maintenance costs are not considered. There are two types of dispatch strategies in HOMER, load following and cycle charging strategy. In the load following strategy, generators or grid supplies the power just to meet

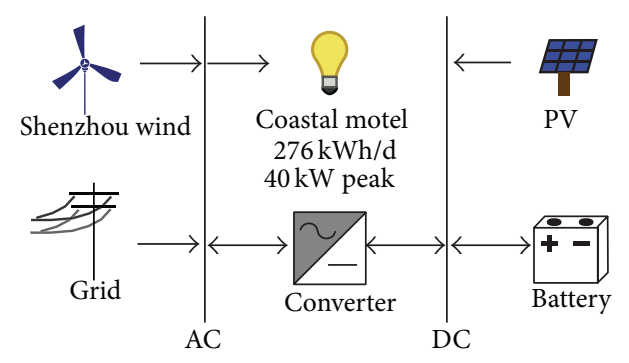

FIGURE 6: Grid-RES hybrid system.

the demand that is not fulfilled by RES. On the other hand, in the cycle charging strategy, generators run at full capacity and any excess electricity is stored in batteries [38]. In the present work, load following strategy is considered. System fixed capital cost is assumed to be $\$ 1000$ considering land cost, LT (low tension) grid side connection cost, and so forth. It is required to consider operating reserve in designing power system because electric load can fluctuate to a level above rated demand suddenly. A system that includes wind and solar power sources requires additional operating reserve to guard against such random increase in demand or shortage in renewable supply. Operating reserve is considered $10 \%$ of hourly load as recommended by Cotrell and Pratt [39].

\section{Results}

In this study, several system configurations are considered. Off-grid-RES and on-grid-RES are compared on the basis of economy with grid only system. The basic system configuration with all system elements considered in this study is shown in Figure 6. For off-grid system, two scenarios regarding annual electricity shortage are considered. In the first scenario, no annual shortage is considered and, in the second scenario, $8 \%$ annual electricity shortage is considered. In the subsequent sections, optimization result and sensitivity result are shown for different configurations.

8.1. Grid Only System. In this case, the NPC is $\$ 129,209$ over the project lifetime of 25 years. The cost of per unit energy (COE) is $\$ 0.113$ at the 2014 electricity purchase rate. NPC increases in direct proportion to increase in electricity price. Greenhouse gas (GHG) emissions are 63,668 kg per year. The total electricity purchase from distribution companies for 1 year is $100,740 \mathrm{kWh}$. Figure 7 shows the monthly purchase of electricity from grid.

8.2. RES Only System. HOMER simulation shows that a RES only configuration is technically feasible with available renewable resources. Search space (sizes and quantities to consider that is given as input) is shown in Table 7. This search space is created after many trials and errors, eliminating inefficient entries to reduce simulation time.

HOMER predicts that a configuration of $54 \mathrm{~kW} \mathrm{PV}, 17$ wind turbines ( $10 \mathrm{~kW}$ each), $40 \mathrm{~kW}$ converter, and 290 nos twelve (12) $\mathrm{V}$ batteries is the only economically feasible 
TABLE 6: Economic parameters of system components.

\begin{tabular}{lcccc}
\hline Characteristics & PV module & Wind turbine & Battery & Converter \\
\hline Model & Typical & EW10000 & Electrosolar & $\begin{array}{c}\text { Nominal voltage } 12 \mathrm{~V} \\
\text { Nominal capacity } 130 \mathrm{Ah}\end{array}$ \\
\hline Power & $250 \mathrm{~W}$ & $10 \mathrm{~kW}$ & Lifetime throughput 2230 kWh & $2 \mathrm{~kW}$ \\
\hline Lifetime & 25 years & 9 years & $\$ 260$ & 15 years \\
\hline Capital & $\$ 355[20]$ & $\$ 10000[21]$ & $\$ 260$ & $\$ 730[22]$ \\
\hline Replacement & $\$ 300$ & $\$ 9,000$ & $\$ 12.50$ & $\$ 730$ \\
\hline Maintenance & $\$ 7$ & $\$ 13$ & $\$ 7$
\end{tabular}

TABLE 7: Search space.

\begin{tabular}{lccc}
\hline $\begin{array}{l}\text { PV array } \\
(\mathrm{kW})\end{array}$ & $\begin{array}{c}\text { Wind turbine } \\
\text { (EW10k) } \\
\text { (quantity) }\end{array}$ & $\begin{array}{c}\text { Battery } \\
\text { (ElecSol12) } \\
\text { (strings) }\end{array}$ & $\begin{array}{c}\text { Converter } \\
(\mathrm{kW})\end{array}$ \\
\hline 0 & 0 & 0 & 22 \\
5000 & 9 & 40 & 25 \\
15000 & 10 & 45 & 28 \\
20000 & 11 & 50 & 30 \\
25000 & 12 & 55 & 35 \\
30000 & 13 & 60 & 40 \\
35000 & 14 & 65 & \\
40000 & 16 & 70 & \\
50000 & 17 & 80 & \\
60000 & 18 & 90 & \\
\hline
\end{tabular}

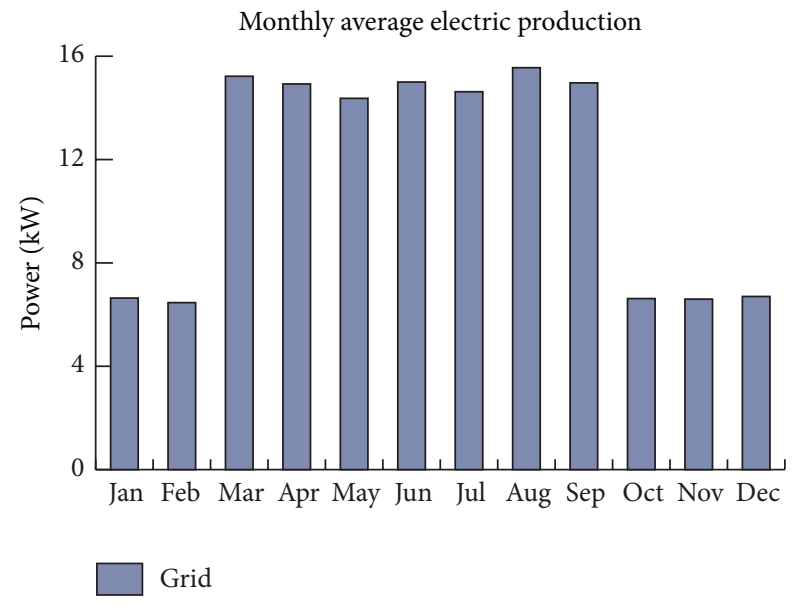

FIGURE 7: Monthly purchase of grid electricity.

solution at zero annual electricity shortage. NPC of this configuration is $\$ 642,262$ and COE is $\$ 0.56$. On the other hand, if $8 \%$ annual electricity shortage is considered, a configuration of 11 wind turbines ( $10 \mathrm{~kW}$ each), $20 \mathrm{~kW} \mathrm{PV}$, a $25 \mathrm{~kW}$ converter, and 120 nos twelve (12) $\mathrm{V}$ batteries provides the lowest NPC of $\$ 317,591$ (Table 8, option 1). Another configuration of $14 \mathrm{WT}$ with $25 \mathrm{~kW}$ converter and 130 nos batteries gives NPC of $\$ 338,676$ (Table 8 , option 2). If $125 \mathrm{Wp}$ solar panel is considered, then 8 panels are needed to yield $1 \mathrm{~kW}$ PV array.

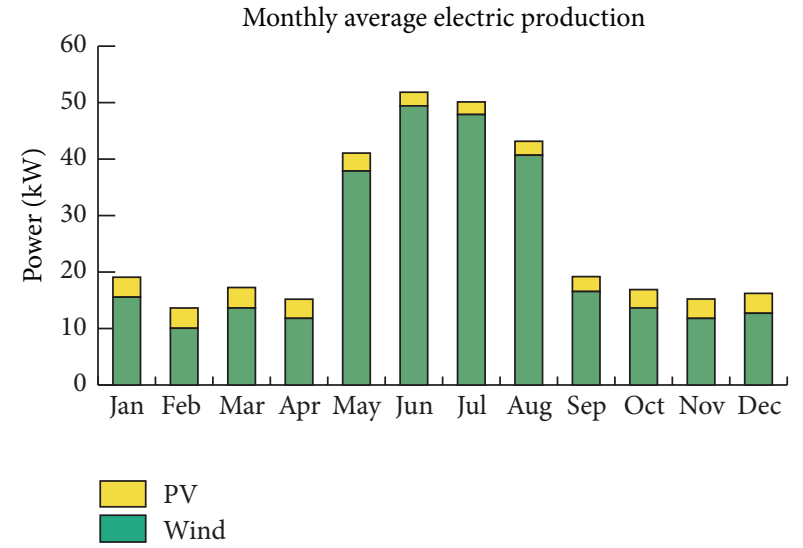

FIGURE 8: Monthly average electricity production in PV-WT configuration at $8 \%$ shortage.

Considering $125 \mathrm{Wp}$ solar panel size $64.25 \times 38.82$ square inches [32] or 1.60915 square meters, $1 \mathrm{~kW} \mathrm{PV}$ array covers 12.8732-square-meter area. So footprint required for PVwind-battery hybrid system would be roughly 28050 square meters including spacing for battery banks and converters. Footprints required for wind-battery-converter hybrid system would be roughly 35250 square meters. The monthly average electricity production from PV-wind-battery hybrid system at $8 \%$ annual electricity shortage is shown in Figure 8.

8.3. Grid-RES Hybrid. From HOMER simulations it is found that grid tied RES is technically feasible with present renewable resource. It is also economically lucrative. Optimization result of simulation for this system configuration is shown in Table 9. From Table 9 it is found that 6 grid tied wind turbines give an NPC of $\$ 147,899$ which is $13.85 \%$ higher than that of the grid only configuration (Table 9, option 2). Renewable fraction (RF) for the configuration is $75 \%$. COE is $\$ 0.129$. Battery and inverter are not required in this configuration, as the grid network acts as the backup reserve. Greenhouse gas (GHG) emissions are 23,523 kg per year. Excess electricity is $23.4 \%$. The addition of $5 \mathrm{~kW}$ of $\mathrm{PV}$ with 6 wind turbines increases the RF to $77 \%$ (option 4 in comparison to option 1). GHG emission in this option is $22,446 \mathrm{~kg} /$ year which is $64.75 \%$ less than grid only system. A comparison of GHGs emission for grid only, grid-wind, and grid-PV-wind system 
TABLE 8: RES only configuration optimization result.

\begin{tabular}{|c|c|c|c|c|c|c|c|c|c|c|c|c|c|}
\hline . & t & (1) & $\nabla$ & $\begin{array}{c}\mathrm{PV} \\
(\mathrm{kW})\end{array}$ & EW10k & ElecSol12 & $\begin{array}{l}\text { Conv. } \\
(\mathrm{kW})\end{array}$ & $\begin{array}{l}\text { Initial } \\
\text { capital }\end{array}$ & $\begin{array}{l}\text { Operating } \\
\text { cost }(\$ / y r)\end{array}$ & $\begin{array}{l}\text { Total } \\
\text { NPC }\end{array}$ & $\begin{array}{c}\mathrm{COE} \\
(\$ / \mathrm{kWh})\end{array}$ & $\begin{array}{l}\text { Ren. } \\
\text { frac. }\end{array}$ & $\begin{array}{l}\text { Capacity } \\
\text { shortage }\end{array}$ \\
\hline \multirow[t]{2}{*}{ 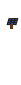 } & r & $\oplus$ & 叉 & 20 & 11 & 120 & 25 & $\$ 179,725$ & 12,098 & $\$ 317,591$ & 0.292 & 1.00 & 0.08 \\
\hline & + & $\oplus$ & $\nabla$ & & 14 & 130 & 25 & $\$ 183,925$ & 13,580 & $\$ 338,676$ & 0.311 & 1.00 & 0.08 \\
\hline
\end{tabular}

TABLE 9: Grid-RES configuration optimization result.

\begin{tabular}{|c|c|c|c|c|c|c|c|c|c|c|c|c|c|c|}
\hline-1 & . & i & च & $\nabla$ & $\begin{array}{c}\mathrm{PV} \\
(\mathrm{kW})\end{array}$ & EW10k & ElecSol12 & $\begin{array}{l}\text { Conv. } \\
(\mathrm{kW})\end{array}$ & $\begin{array}{c}\text { Grid } \\
(\mathrm{kW})\end{array}$ & $\begin{array}{l}\text { Initial } \\
\text { capital }\end{array}$ & $\begin{array}{l}\text { Operating } \\
\text { cost }(\$ / y r)\end{array}$ & $\begin{array}{l}\text { Total } \\
\text { NPC }\end{array}$ & $\begin{array}{c}\mathrm{COE} \\
(\$ / \mathrm{kWh})\end{array}$ & $\begin{array}{l}\text { Ren. } \\
\text { frac. }\end{array}$ \\
\hline 4 & & & & & & & & & 10000 & $\$ 1000$ & 11,312 & $\$ 129,909$ & 0.113 & 0.00 \\
\hline 4 & . & & & 叉 & 5 & & & 22 & 10000 & $\$ 16,255$ & 11,241 & $\$ 144,351$ & 0.126 & 0.07 \\
\hline 米 & & $\lambda$ & & & & 6 & & & 10000 & $\$ 61,125$ & 7,615 & $\$ 147,899$ & 0.129 & 0.75 \\
\hline क & 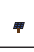 & i & & $\nabla$ & 5 & 6 & & 22 & 10000 & $\$ 76,255$ & 7,882 & $\$ 166,079$ & 0.145 & 0.77 \\
\hline
\end{tabular}

TABLE 10: Comparison of greenhouse gas emissions of 3 systems.

\begin{tabular}{lccc}
\hline \multirow{2}{*}{ Pollutant } & \multicolumn{3}{c}{ Emissions (kg/yr) } \\
& $\begin{array}{c}\text { Grid only } \\
\text { system }\end{array}$ & $\begin{array}{c}\text { Grid-wind } \\
\text { system }\end{array}$ & $\begin{array}{c}\text { Grid-PV-wind } \\
\text { system }\end{array}$ \\
\hline Carbon dioxide & 63668 & 23523 & 22446 \\
Carbon monoxide & 0 & 0 & 0 \\
Unburned hydrocarbons & 0 & 0 & 0 \\
Particulate matter & 0 & 0 & 0 \\
Sulfur dioxide & 276 & 102 & 97.3 \\
Nitrogen oxides & 135 & 49.9 & 47.6 \\
\hline
\end{tabular}

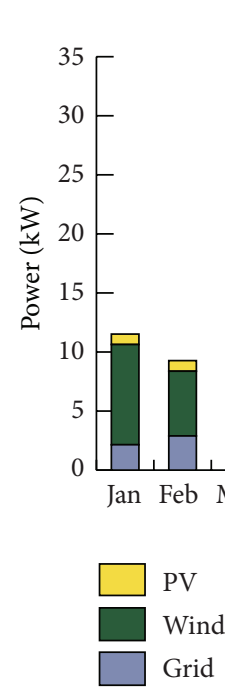

FIGURE 9: Monthly average electricity production in grid-PV-WT configuration.

is shown in Table 10. The monthly average electricity production from grid-PV-wind hybrid system (option 4, Table 9) is shown in Figure 9.

A comparison between system configurations on the basis of economy is provided in Table 11.

\section{Sensitivity Analysis}

In sensitivity analysis, system's control parameters can be varied to examine the effect of control parameters on system's performance. It helps the system designer to choose most economical system configuration for a given range of control parameters. In this study, two types of sensitivity variables are chosen to conduct sensitivity analysis.

Firstly, solar and wind resources are varied from annual average value to determine the effect of resource variation on system economy. Secondly, the capital costs of PV panel and wind turbine are varied.

It is known that the nature of renewable resource is intermittent. Average solar radiation on Patenga varies from year to year, though not significantly. The same is for wind speed, which fluctuates over the year. Random variability factor is also provided in resource input. Resources are varied to make suggestion about system economy if project location is changed.

On the other hand, installation cost of PV array and wind turbine is decreasing over the decades. National Renewable Energy Laboratory (NREL) researchers showed that installation cost of renewable power system is undergoing a downward trend [40, 41]. For these reasons, PV and wind turbine capital costs are varied to determine the effect of capital cost variation on system economy.

9.1. Renewable Resource Variation. In Figure 10, solar and wind resources are varied from annual average value to determine the effect of resource variation on system economy. In the $x$-axis we have plotted solar radiation and varied it from $3.8 \mathrm{kWh} / \mathrm{m}^{2} /$ day to $6 \mathrm{kWh} / \mathrm{m}^{2} /$ day. The reason behind choosing this range is that, according to Figure 2, the annual solar radiation varies within this range annually. The same goes for wind speed. According to Figure 3, the wind speed at target location varies from $2.5 \mathrm{~m} / \mathrm{s}$ to $6 \mathrm{~m} / \mathrm{s}$ annually. So this range for wind speed variation is used.

Now the sensitivity analysis in the HOMER software finds out the most cost effective system for a given set of resources. In Figure 10, when solar radiation is up to $4 \mathrm{kWh} / \mathrm{m}^{2} /$ day, the wind-PV/battery system is more cost effective than 
TABLE 11: Economic comparison between different configurations.

\begin{tabular}{lccccccc}
\hline System & $\begin{array}{c}\text { PV } \\
(\mathrm{kW})\end{array}$ & $\begin{array}{c}\text { WT (10 kW) } \\
\text { (quantity) }\end{array}$ & $\begin{array}{c}\text { Battery } \\
\text { (number) }\end{array}$ & $\begin{array}{c}\text { Converter } \\
(\mathrm{kW})\end{array}$ & $\begin{array}{c}\text { NPC } \\
(\mathrm{BDT})\end{array}$ & $\begin{array}{c}\text { COE } \\
(\mathrm{BDT})\end{array}$ & $\begin{array}{c}\text { Renewable fraction } \\
\text { Grid only }\end{array}$ \\
PV-wind hybrid & 20 & 11 & & & 129,909 & 0.113 & 0 \\
Grid-wind hybrid & & 6 & 120 & 25 & 317,591 & 0.292 & $1(8 \%$ shortage) \\
Grid-PV-wind hybrid & 5 & 6 & & 22 & 147,899 & 0.128 & 0.75 \\
\hline
\end{tabular}

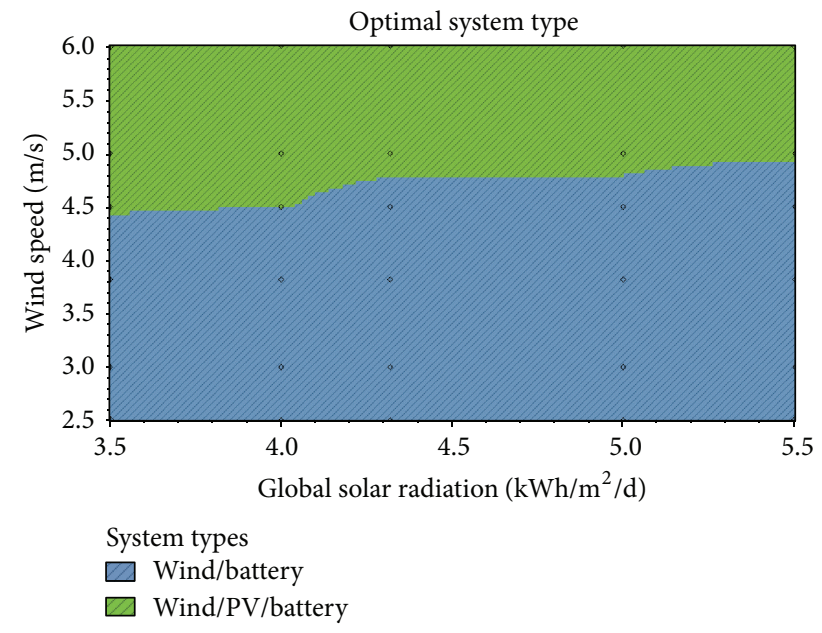

FIGURE 10: Sensitivity result.

wind/battery system for wind speed up to $4.4 \mathrm{~m} / \mathrm{s}$. If the wind speed is higher than that, the wind/battery system becomes more cost effective. Similarly, at solar radiation around $4.3 \mathrm{kWh} / \mathrm{m}^{2} /$ day, the wind-PV/battery system is more cost effective than wind/battery system if the wind speed is less than or equal to $4.8 \mathrm{~m} / \mathrm{s}$. All the analyses are done with the consideration that maximum annual capacity shortage is $8 \%$.

9.2. Capital Cost Variation. HOMER provides option of cost variation of system components. In this study, capital and replacement costs of $\mathrm{PV}$ and wind turbine are multiplied by scaling factors. When cost multipliers are provided, these factors are multiplied by given costs in the cost table. HOMER then simulates system with these varying prices and calculates NPC.

The study [41] showed that per watt installation price of PV panel decreased by around 15\% from 2010 to 2011 and around 30\% from 2010 to 2012. On the other hand, another study [40] showed that cost of energy production in MWh from wind turbine reduces by around 62\% from 1990 to 2000 and around $20 \%$ from 2000 to 2005 . To include this trend in system size optimization, capital cost of PV panel and wind turbine is multiplied by 0.8 and 0.6 , for all system configurations shown in Table 12. COE are reported when both PV panels and wind turbines capital cost are multiplied by the same factor.
TABLE 12: COE of different system configurations with 3 different multipliers.

\begin{tabular}{lcc}
\hline System & Capital multiplier & COE (\$) \\
\hline \multirow{2}{*}{ Grid/wind } & 1 & 0.129 \\
& 0.8 & 0.112 \\
& 0.6 & 0.096 \\
Grid/PV/wind/inverter & 1 & 0.145 \\
& 0.8 & 0.127 \\
Grid/PV/battery/inverter & 0.6 & 0.109 \\
(5 kW PV, 22 kW inverter) & 1 & 0.173 \\
& 0.8 & 0.171 \\
Grid/PV/wind/battery/inverter & 0.6 & 0.17 \\
\hline & 1 & 0.192 \\
PV/wind/battery/inverter & 0.8 & 0.174 \\
& 0.6 & 0.156 \\
\hline
\end{tabular}

From the table it is evident that $20 \%$ reduction of installation cost results in nearly $9 \%-12 \%$ reductions in cost of per unit energy.

\section{Conclusion}

From this study it is clear that, in case of off-grid system, the optimized PV-wind-battery hybrid system is more cost effective compared to wind-alone system, $P V$ alone system, and wind-PV hybrid system for the load with $8 \%$ annual capacity of shortage for this hypothetical system at the proposed site. From the sensitivity analysis, it is also clear that the major portion of the energy comes from wind. The sensitivity analysis also predicts that the reduction of installation cost of PV or wind energy system results in per unit electricity cost that is comparable to the grid electricity price. Furthermore, RES system can reduce GHG emission by a significant amount, thus being friendly to the environment. The analysis can be further improved and system economy can be determined more precisely if more related data like minute-wise load curve, land price, variable interest rate, and environmental hazard effects are taken into consideration. Nevertheless, the initial analysis suggests that grid-RES hybrid system is promising enough to justify 
further effort to collect additional data to perform a deeper analysis.

\section{Conflict of Interests}

The authors declare that there is no conflict of interests regarding the publication of this paper.

\section{Acknowledgment}

The authors are grateful to Dr. Enamul Basher, Professor at the Department of Electrical and Electronic Engineering, BUET, for directing and thoroughly supervising the research work.

\section{References}

[1] Power Division and Ministry of Power, Energy and Mineral Resources, Renewable Energy Policy of Bangladesh, Government of the People's Republic of Bangladesh, 2008.

[2] Power Division, Ministry of Power, Energy and Mineral Resources, and Government of the People's Republic of Bangladesh, "Investment potentials," http://www.pd.gov.bd/user/brec/104/ 110.

[3] Bangladesh Power Development Board (BPDB), "Power generation units (fuel type wise)," 2014, http://www.bpdb.gov.bd/ $\mathrm{bpdb} /$ index.php?option $=$ com_content\&view $=$ article\&id $=150 \&$ Itemid $=16$.

[4] Bangladesh Power Development Board, Annual Report, Bangladesh Power Development Board, 2012-2013.

[5] M. Ahiduzzaman and A. K. M. S. Islam, "Greenhouse gas emission and renewable energy sources for sustainable development in Bangladesh," Renewable and Sustainable Energy Reviews, vol. 15, no. 9, pp. 4659-4666, 2011.

[6] Wikipedia, "List of countries by carbon dioxide emissions per capita," 2014, http://en.wikipedia.org/wiki/Listofcountriesbycarbondioxideemissionspercapita.

[7] Bangladesh Power Development Board (BPDB), Development of Renewable Energy Technologies by BPDB, Bangladesh Power Development Board (BPDB), 2014, http://www.bpdb.gov.bd/ bpdb/index.php.

[8] S. M. Formanul Islam, S. Aziz, and S. A. Chowdhury, "Renewable energy initiatives by infrastructure development company limited in Bangladesh," in Proceedings of the IEEE International Conference on the Developments in Renewable Energy Technology, pp. 202-206, December 2009.

[9] "Wind energy resource mapping (WERM) in Bangladesh," Project Report, Local Government Engineering Department (LGED), Government of the People's Republic of Bangladesh, Dhaka, Bangladesh.

[10] Surface meteorology and Solar Energy, a renewable energy resource website, sponsored by NASAs Earth Science Enterprise Program, 2014, https://eosweb.larc.nasa.gov/sse/.

[11] A. H. Mondal and M. Denich, "Hybrid systems for decentralized power generation in Bangladesh," Energy for Sustainable Development, vol. 14, no. 1, pp. 48-55, 2010.

[12] M. A. H. Mondal, L. M. Kamp, and N. I. Pachova, "Drivers, barriers, and strategies for implementation of renewable energy technologies in rural areas in Bangladesh-an innovation system analysis," Energy Policy, vol. 38, no. 8, pp. 4626-4634, 2010.
[13] J. L. Bernal-Agustín and R. Dufo-López, "Simulation and optimization of stand-alone hybrid renewable energy systems," Renewable and Sustainable Energy Reviews, vol. 13, no. 8, pp. 2111-2118, 2009.

[14] S. K. Nandi and H. R. Ghosh, "A wind-PV-battery hybrid power system at Sitakunda in Bangladesh," Energy Policy, vol. 37, no. 9, pp. 3659-3664, 2009.

[15] L. Xu, X. Ruan, C. Mao, B. Zhang, and Y. Luo, "An improved optimal sizing method for wind-solar-battery hybrid power system," IEEE Transactions on Sustainable Energy, vol. 4, no. 3, pp. 774-785, 2013.

[16] D. B. Nelson, M. H. Nehrir, and C. Wang, "Unit sizing and cost analysis of stand-alone hybrid wind/PV/fuel cell power generation systems," Renewable Energy, vol. 31, no. 10, pp. 16411656, 2006.

[17] M. Alam Hossain Mondal and A. K. M. Sadrul Islam, "Potential and viability of grid-connected solar pv system in Bangladesh," Renewable Energy, vol. 36, no. 6, pp. 1869-1874, 2011.

[18] J. A. Razak, K. Sopian, and Y. Ali, "Optimization of renewable energy hybrid system by minimizing excess capacity," International Journal of Energy, vol. 1, no. 3, 2007.

[19] T. Lambert and L. P. Homer, "The micro-power optimization model," software produced by NREL.

[20] LG solar panel model LG-295N1C, 2014, http://www.wholesalesolar.com/products.folder/module-folder/LG/LG250S1C-G2 .html.

[21] 10KW on-grid and off-grid wind turbine generator system, 2014, http://shenzhougenerator.en.alibaba.com/product/555911860221402430/10KWongridandoffgridwindturbinegeneratorsystem .html.

[22] 2kw grid tie power inverter, 2014, http://www.alibaba.com/product-detail/2kw-grid-tie-power-inverter-off_664680451.html.

[23] S. Rangarajan, M. S. Swaminathan, and A. Mani, "Computation of solar radiation from observations of cloud cover," Solar Energy, vol. 32, no. 4, pp. 553-556, 1984.

[24] A. Nyberg, "Determination of global radiation with the aid of observations of cloudiness," Acta Agriculturae Scandinavica, vol. 27, no. 4, pp. 297-300, 2009.

[25] M. R. Rietveld, "A new method for estimating the regression coefficients in the formula relating solar radiation to sunshine," Agricultural Meteorology, vol. 19, no. 2-3, pp. 243-252, 1978.

[26] K. K. Gopinathan, "A general formula for computing the coefficients of the correlation connecting global solar radiation to sunshine duration," Solar Energy, vol. 41, no. 6, pp. 499-502, 1988.

[27] R. B. Benson, M. V. Paris, J. E. Sherry, and C. G. Justus, "Estimation of daily and monthly direct, diffuse and global solar radiation from sunshine duration measurements," Solar Energy, vol. 32, no. 4, pp. 523-535, 1984.

[28] H. Ögelman, A. Ecevit, and E. Tasdemiroğlu, "A new method for estimating solar radiation from bright sunshine data," Solar Energy, vol. 33, no. 6, pp. 619-625, 1984.

[29] J. A. Prescott, "Evaporation from water surface in relation to solar radiation," Transactions of The Royal Society of South Australia, vol. 40, pp. 114-118, 1940.

[30] Weatherspark, a weather based website https//weatherspark .com/.

[31] M. G. Uddin, Bangladesh Meteorological Department (BMD), 2014.

[32] A. Demiroren and U. Yilmaz, "Analysis of change in electric energy cost with using renewable energy sources in Gökceada, 
Turkey: an island example," Renewable and Sustainable Energy Reviews, vol. 14, no. 1, pp. 323-333, 2010.

[33] Bangladesh Power Development Board, "Retail tariff rate," 2014.

[34] L. Shenzhou Wind-driven Generator Co., http://f-n.cn.

[35] P. Denholm, M. Hand, M. Jackson, and S. Ong, "Land use measurement of modern wind power," Tech. Rep., National Renewable Energy Laboratory, 2009, http://www.nrel.gov/docs/ fy09osti/45834.pdf.

[36] Electro Solar Power, http://www.electrosolarbd.com/.

[37] Bangladesh Bank, "Interest rates," December 2014, https://www .bb.org.bd/econdata/intrate.php.

[38] S. Lal and A. Raturi, "Techno-economic analysis of a hybrid mini-grid system for Fiji islands," International Journal of Energy and Environmental Engineering, vol. 3, article 10, 2012.

[39] J. Cotrell and W. Pratt, "Modeling the feasibility of using fuel cells and hydrogen internal combustion engines in remote renewable energy systems," Tech. Rep., National Renewable Energy Laboratory, 2003, http://www.nrel.gov/docs/fy03osti/ 34648.pdf.

[40] E. Lantz, R. Wiser, and M. Hand, "The past and future cost of wind energy," IEA Wind Task, 2012.

[41] D. Feldman, R. Barbose, R. Margolis, R. Wiser, N. Darghouth, and A. Goodrich, "Photovoltaic system pricing trends: historical, recent, and near-term projections," Tech. Rep., National Renewable Energy Laboratory, 2013. 


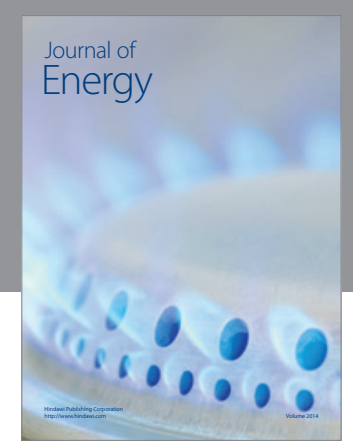

Journal of

Industrial Engineering
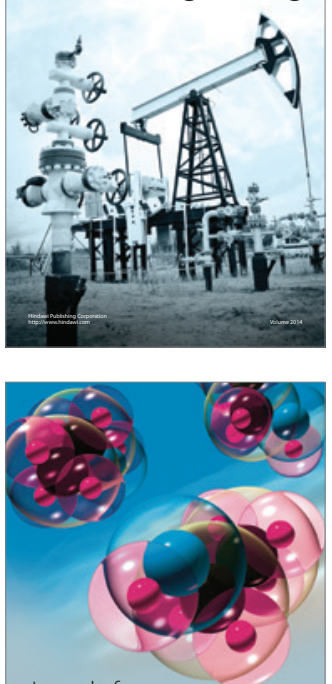

Fuels
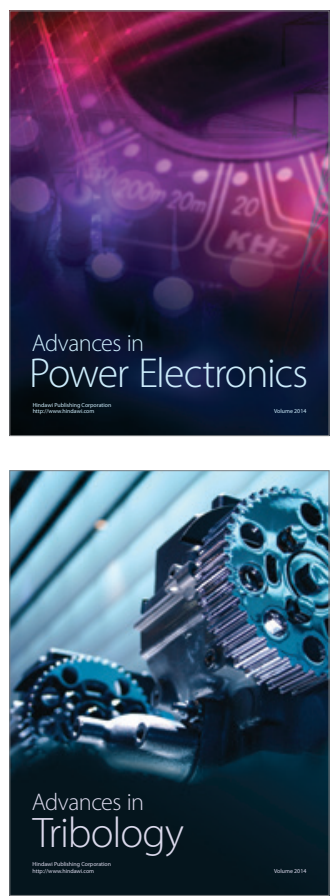

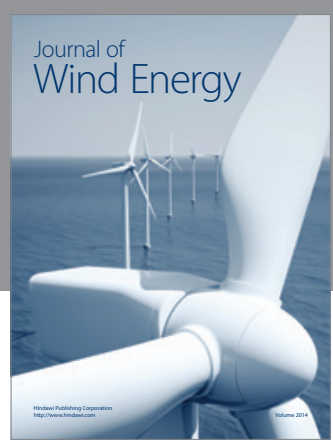

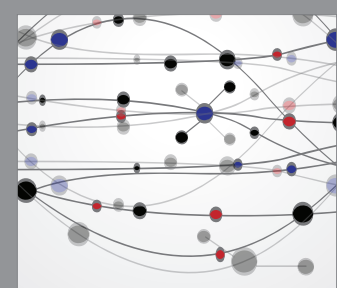

The Scientific World Journal

Submit your manuscripts at http://www.hindawi.com

Journal of

Structures
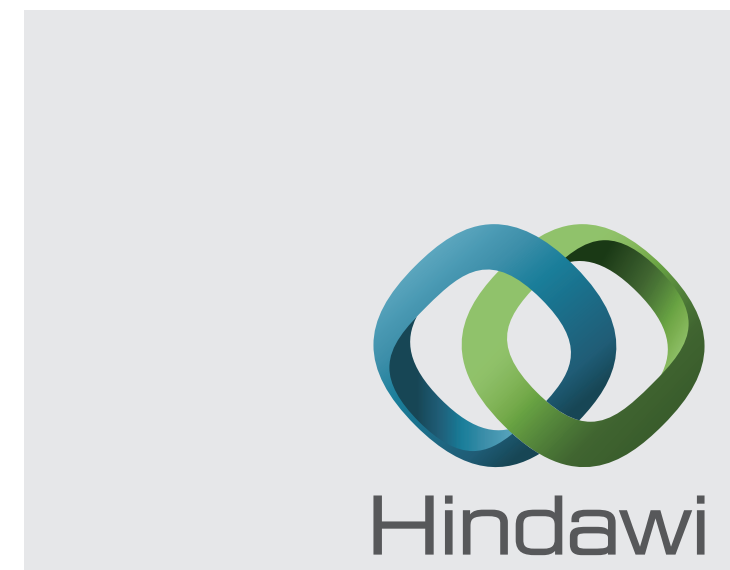

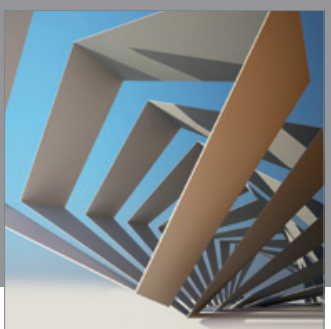

Rotating

Machinery
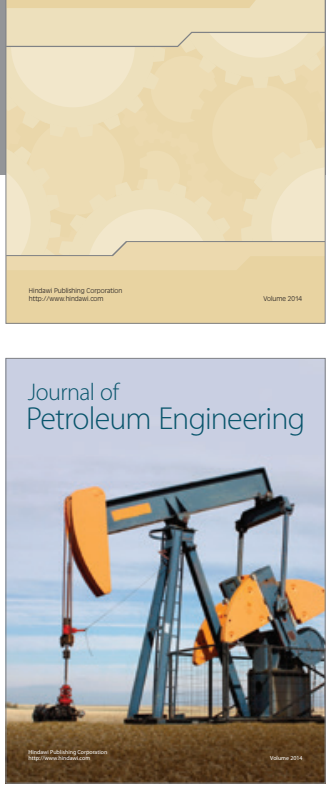

Journal of

Solar Energy
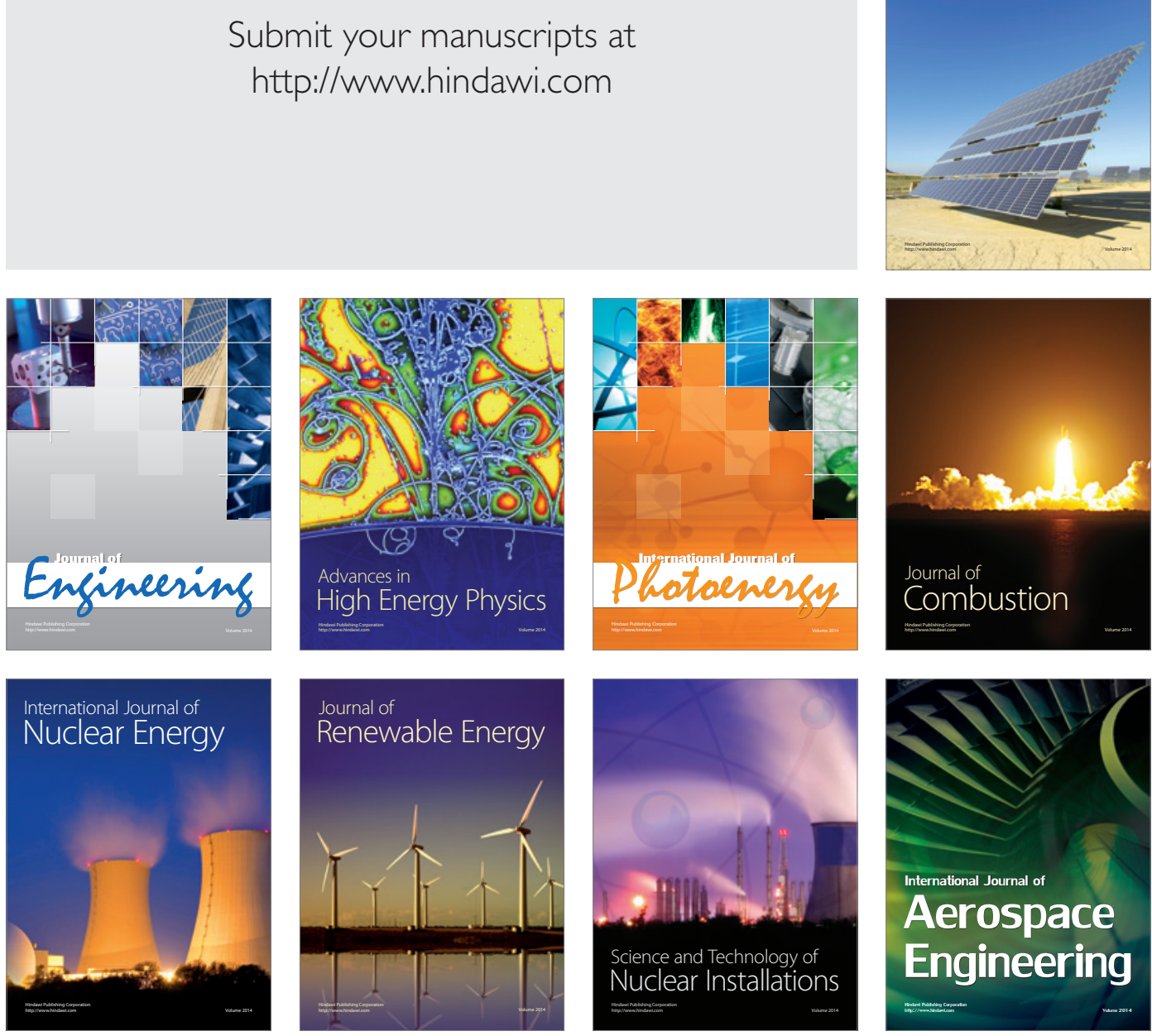